\title{
Style and Stylistic Language of the Texts inModern Criticism In the light of "Old Critical Systemof Rhetorical Imagesin Arabic"
}

\author{
Prof. Dr. Salahuddin Mohd. Shamsuddin \\ Dept. of Arabic \& Middle Eastern Languages, Faculty of Languages and Linguistics, \\ University of Malaya, 50603 Kuala Lumpur, Malaysia
}

\begin{abstract}
This article is an attempt to explain the definition of "Style"as the word and its meaning, studying the opinions of Contemporary Researchers in the "Style". We note that this term has disappeared from the mainstream of Modern Criticism at the time the term "Stylistic" taken its place crystallizing and forming its features and become a semi-independent study.

We highlightthe difference between the Stylistic Study and Literary Criticism.The scientific aspect of stylistic studyis derived from the Modern Linguistics. Its literary side is based on the literary criticism. Therefore the stylistic study is counted a separating zone between the two types of study, but its feature has not determined yet perfectly.

We study this topic in the light of "Old Critical System of Rhetorical Images in Arabic", becausethere is a disorder and confusion between the stylistic terms and literary criticism, especially modern literary doctrines, such as Romanism, Realismand others. These literary doctrines were borrowed and were useful in the development of Modern Literary Criticism in Arabic, after the development of Arabic Literature through its connection to European Literatures in Modern Era. We also study the link between the Originality and Modernity of Rhetorical Studiesin Arabic.
\end{abstract}

Keywords: Words, Construction of Sentences, Stylistic Study, Literary Criticism, System of Speech, Rhetoric Sciences in Arabic.

\section{Definition of the "Style"}

The writer uses a special language in his writing, and this isa fact naturally, because every writer has an independent personality, it means that he has his own language, or his own style. As:

- (Buffon) has saidin ancient time: "The style is the man himself." (1)

- As well as (Flaubert) also has defined the style, saying that: "It is anespecial way of writer to see the things (around him)." (2)

- The special way of writer in his sense and vision imposes a special way in the use of language.

Hence, the sincere style must be unique if we understand the term "SincereStyle"linguistically, meaning that it iscompletely enough to express the way of writer in his feeling.

This means that the style is not just a method of writing learntby the learners willingly, but it belongs to the special inspiration to every writer,pushes him to write, which constitutes this writing.Therefore, it is the way that this inspiration pushes that particular man to write.

The style isa linguistic recipe to describe the connectionof author to the deep emotions or ideas or a range of emotions and ideas, where if the thought overcomes the expression, the expression becomesa prose and if the passion prevailsit becomes either a prose or poetry. The style is a speech when theexpression of thought or emotion reaches the fullest form...The style depends entirely on this exactconnection, if there is no exactconnection there is no style. (3)

In brief, the style is a special way of the writer in his thinking, feeling andtransferringthis feeling in the form of his special language. The style will be a good style according to the degree of success in transferring it to the others.

The search in the nature of the style was a problem since the time of Plato.The styleasPlatonic point of the viewin the recipe is a special quality, it is not something to be added to the writers, as it is not just a form wherethe writing placed, but a recipe - if it is found -found in which has been written.

In order to understand Platonic point of the view in the stylewe have to know fully the meaning of the word:(Logos) to Plato. The word: Logos has been dealing with the same idea and its exterior reality, which emergesin the image of the word generally. Therefore, the word means the idea, as well as it will be concerned with the idea when it will be presented outside. (4) 
This is a logical talk as Westland says (5): We can not disagree with it,as it is just a thought. He adds that we must recognize that there are degrees of success vary between the perfection and failure, and that the work of writer can be closer to the full expression of the meaning, and that the proximity to the sanctify means that resulted from the choice of the words or their arrangement has not completed all the perfection. (6)

We can say in brief that the style is seen asone point of the view, asit is a special thinking style and as another point of the view, it is a special expressive style.

When we look at the style as an intellectual skill, the linguistic expression is nothing only an achievement of the idea into the appropriate sensory image. It means that the only Ideaisthe basis of the style according to Buffon and Plato as we have seen before. When we looking at the styleas a expressionistic skill,the thought can not be as a material of the artwork Basically, and a material of the technical workcan not determine the image and its characteristics, because it happens that the material is one, but the writer makes it in another image and there isa disparity between them in the reality... The solution about this confusion demands that the style should be realized as a mental status emerged inthe language, and then a language of the writer would be personal... We find the writer uses the dominant language in his society - in order to transfer his ideas and feelings to the others - because he has to use the "currency" which is deal by the people. For the evidence, we do not find any writer in this century, uses the language of the Medieval Ages. We also find that each writer has his own style which distinguishes him from the other writers. (7)

\section{A. The Style as the word and its meaning}

However, there are three distinct meanings of this word (style)in the West that are free from any limitation, namely:

1. "Style" in the sense of personal privacies and individual characteristics.

2. "Style" in the sense of a technicalpresentation and statement.

3. "Style" which is the highest achievement in the literature.

It is noticeable that there is a disorder and confusion between these three meanings. We may say that the critic has to explain through the context which is usedfor the meaning of the word, but the fact says that he rarely does. However, the criticmust be a creative artist in his criticism, because the first part of his work is the transfer of influence, means every experience that he gets through the study of literary work as an impact in the same, like the intellectual and emotional impression and without this his critique will be trivial which has no basis. In this account, his mission is perfectly equalwith the mission of a creative writer. (8)

\section{B. Opinions ofContemporary Researchers in the "Style"}

Some contemporary scholars said that when we talk about the term (style) find that there is some notablecontradiction. We see that this term has disappeared from the mainstream of the modern criticism, at the time the term (stylistic)took its place crystallizing and forming its features and become a semi-independent study. This may be due to the modern critical thinking which prevailed because of the unit of the literary work in the form and content or style and themewithout any separation between them, but this aesthetic principle beyond the scope of the art of literature has become recognized in the non-literaryexpression too, as evidenced in a saying spoken by Bloomfield acknowledgesabout the linguistic hypothesis that"the disparate phrases in the shape are always varying in the sense". On this we can not talk about the different ways to express one idea, but we talk about different ideas, therefore, the stylehas no existence. Richard Ohemanhas clarified this issue very clearly, he said: "because if there is no recognition for the different ways to express something thenwhat can be deserved to be called a style?" The critic can talk about what the writer says, but he can not speak about his style, because the identity of the author -which is known by his thought andmold- does not have any way for the personal disparatewhich is usually called style, and then the stylebecomes a hypothesis structure which has no use. (9)

However, many critics in the linguistic area who were interested in the style,satisfied completely about the different ways of expressing one thing. In this regard,Hockettsays: "Two phrases from one language, expressingalmostthe same meaning, but they differ in their linguistic construction, can be said about both of them that they differ in the style."(10)

This argument represents in fact an essential basis to those who said in the definition of the stylethat it is a "choice". The owners of this opinion vary in their routes to determine the meaning of "choice". Some believe that there are two types of the choice.The first is governed by the position and place, which is called the utilitarianchoice: (Pragmatic Selection).The second is controlled by the requirements of exclusive expression, which is called (Grammatical Selection). The second type:The grammatical choice is meant by the Grammar which is more general than the grammatical rules that are known in Arabic, so as to include the common rules of the language in its voices and Morphology and its dictionary, systems of the sentences, and this selection is found whilethe writer prefers a word leaving the other the word or a complex sentence to the other, because it is 
healthier or more accurate to explain what he wants. Here, Saa ‘d Mașlūh points out that this kind of the choice includes many rhetoricalthemes that known, such as "the separating and Joining", "the preceding and delaying" and "thementioning and deleting". According to the owners of this opinion the final form of the text is fixed by these two types of the selection, but the term (style) basically belongs to the second type. Finally, he concludes the distinction between these two types, he says: "The choice will be utilitarian whilethe selection will beamong the different attributes that mean differentsignificances and it will be stylistic if it will be among the different attributes that mean the one significance." (11)

There are two types of the choice exercised by the writer or author in the opinion of another group of the critics who say that the style is "a choice",meaning the side of sense.The firstis the choice of subject (Matter) in the broadest sense of the word, and this kind of the choice is a preliminary thing,but it is not a basis of the style. The second choice is the stylistic choice, because it is a choice between the multiple lexical vocabularies and Syntactic Resources for the specific language.

It can be said about this kind of the choice that it is the best linguistic way to express a particular topic or it can be said that it is a choice among the multiple meanings or shades of the meaning which revolves around the particular topic. It is possible to countthis choicea description used for the subject and appropriate ora description used -perhaps unconsciously- for the author's personality and his temperament. Whatever the opinion can be in this regard, the subject of study and debate is the Verbal Ordinance, which is not a summary of the myth or facts of the present case or the ideological or biographicalbasis.

However, the stylistic problem is limited in the scientific research, because the choice is extremely tighthere. The sense has no place in the scientific research, as well as the tone (the attitude toward the reader): any neutral tone which means that the verbal sophistication is unnecessary or it is prohibited, however, the stylistic choice remains existed. Therefore, it is possible to announce the subject of research, and describe the means used practically in its examination and achievement, and mention the results in various ways, for example briefly or in full detail, in the clarity or ambiguity. As well as it is possible to write the research raises the curiosity and makes it convincing psychologically and logically in appropriate points.All these things are the parts of what we call a style. (12)

The literary context in its narrow senseis that the subject always has much complex, and the potential choice can be a lot or more than which is available in scientific research, so the awareness of author about the subject and his position to the reader,both have their importance and place.Here it is not suitable to talk a lot about aPredetermined-Subject.The writer may choose a way from the multiple ways to express it. The awareness and the tone both are two partsof what is used to express it as they both are two parts of the meaning and they are not for the additional beauty or means of the attraction. Whatever one thinks of them, they can be the subject of study and the verbal means that can decide the position of the author and can make it under the consideration, so choosing this word instead of that, choosing this kind of grammatical structures instead of that is a concrete reality can be examined and its elements can be studied.

The organic unity of the literary work is not something ready, such as the pearls lying latent in the nature untouched by anyone, but it is something that is achieved in various ways, the reluctant rhythm may be in the mind of lyric poet before he knows the suitable words for it, and may he imaginestanzas of the poem or phrases before he knowswhat will revolve around the poemconcerning it.There are only a very few cases in which the poet discovers the whole poem as the specified shapein its final form. However, the writer of Expository Prose begins the writing about an issue andhis consciousness about it may be vague generally, but it can not be hold together and refined only if it is produced in an appropriate system of the structures and vocabulary. The novelist may be aware of the personalities and narrative attitudesin his story such as asimilar way to hisawareness aboutthe personalities and attitudes in the life, without any thinking to present it linguistically. Almost all types of the writing require a revision process, and this process either can be done on the paper or in the mind of the author before writing.

The writers vary in their views of this process. Some see it as a progress in working towardsmaking it more accurate to the embodiment of a meaningimaginedpreviously.Some others see it as a process of changingcontinues in the same meaning.In both cases it is goodfor the critic to look at the topic asan anticipation and aspiration, the literary work is a project or plan, when it will be in its full form the result will be a single unit (Unity), which means an integrated whole, as we can do the process of abstraction, that we can be aware of them separately and independently from each other, then we can study each of them as the additive parts ofthe whole (project), the magical word that is in a particular stanza ofthe poem perhaps lacks the effectiveness and impact in other sentence, for the example, the structure which is bad in a context, perhaps can serve the goals expressed in another context. The study of style is interested inthese phenomena, whatever ourphilosophy can be in the sense and whatever our theory can be in the psychology of processof the creative. (13)

In the context of a focus on linguistic material in the definition of the style, there is another definition done by some critics, that the style in any literary text is a deviation from the model of speech (which belongs to the model of speech contextually), then this model is a standard pattern as the styles of the texts are measured by 
this standard model, that are consistent with it in the context. Some of these critics -likeUllman- point to thesedeviations and interpret them, while others are trying to explain them by some statistical terms. (14)

Here we can remember what is said by 'Abdul Qāhir Al-Jurjānī, about the drumbeat of two poets on the same meaning, so we see both of them have developed their meaning and picture. (15)

In this case some of the modern critics see that we have to consider one of the explanations doneby both poets a standard example and the other a deviation with that standard example. In fact, it does not need to make one -certainly- standard style and the otherdeviant style, the difference shows that the first style is the standard, and the second is a deviant style, because this matter belongs tothe comparison to note the differences deeply between the two texts to explain the preference.The theory of the Subsequent liked to the Previous is sufficient to indicate that the credit always goes for theprevious one. Therefore, AbdulQahirdid not fixe a specific description to prefer the one likely on the other, but he preferredthe text advanced in the time as the standard example and the other text which appeared laterthe deviantstyle.According to the concept of 'Abdul Qāhirthere is no way to prefer one of two styles on the other, because each of them has imagined his own style. However, it is different to Al-'Amidī (died: $37 \mathrm{H}$.) in the different meanings that were chosen byboth of the poets ('AbuTammam) and (Buhturī), as he did not follow rule of the time to mention the standard poetic model of the text, which was followed by the deviant text, but he judged their quality, shortcomings and weaknesses, asthere was the sample of the text corresponded in his mind, which was derived from his literary taste and experience in the poetic styles and his trained artistic sense. The similarity then between thecourse of Al'Amidīwriter ofthe book: (The Comparison) and the course of 'Abdul 'Azīz Al-Jurjānīthe judge writer of the book:(The Mediation) on the one hand, and between the position of modern stylistic critics on the other hand is not in the power of the similarity between them and 'Abdul Qāhir, because there is nothing in this case except the idea that there are two similar versions in the same context in front of the eyes of critic, and after that the area of dispute remainsa short between the two sides, and the highlighted places of thedifferenceare absence of the critical comparisonsatthe old Arab critics, because of searching the linguistic features in both texts to indicate the amount of deviation or disparity between thelinguistic asymmetric of both texts, and the results and indications that are built on that. This procedure is the core of stylistic analysis at those who say that the style of text is a deviation from the modelcloses to it in the context.It is possible to explain the reason thatstanding of Arab critics at one or two lines of the poem or a little more was a reason of searching the linguistic characteristics in both texts at the comparison between them, where the spaceis not wide for it, as it is wide in a full poetic worksomehow.

There is another trend which is near to the previous trend in determining the meaning of style, looksat the style as it is an Addition. The cause of the nearness between these two trends is that there are also two expressions, measuring one on the other, but the difference is that there are some certain characteristics for one ofthem,because of thatcharacteristics it has counteda model or a standard expression as the other expressionis measured onit,to show the deviation from the first format. Here the criterion is only an expression naked linguistically from the means of influencing, leads directly to the enough meaning, then the style as being an addition to the linguistic characteristics was not existed before, increases the force of meaning and its impact.

It is noted that the definition of the stylewhich see that it is an addition,assumes the existenceof a pattern of saying that leads toa meaning, but it does not rise to the degree that carry then the term (Style) for it does not have anyspecific stylistic feature, therefore, it iscalled the non-stylistic expression or Pre-stylistic expression. (16)

As well as -as said 'Abdul Qāhir Al-Jurjān̄̄- "You see a poets hasbrought the meaning within the anonymous naive, and the other has narrated in the form of liking and exclamation point" (17), but "Abdul Qāhircounts both expressionsa systems and a style, although one of them prefersthe other one, but the first one is better than the other.

If we look at the definitions of (Style) mentionedabove we found out that these definitions do not differ fundamentally, they are closer to the agreement more than the disagreement. It can be said arguably thatthey are more integrated than being distinct and independent from each other, they all share one thing, which is that they presupposes the existence of an feature or several features unique to the style and differentiate between the language and style. (18)

Some researchers have called this type of the study:(Descriptive Stylistic Study) or (Science of Descriptive Style).Shukri'Ayād points out that the French school is the most important Stylistic school that gave full attention to this aspect of the study, meaningthe stylistic characteristics of the national language (French). French have several detailed books of the assets (the Science of French Style) begin from the study of the word, from both sides: the voice and meaning, and end studying the types of sentences and the rhythm of the phrase. The first generation of the French scientists of the style count this study the ultimate goal of the Stylisticscience, and they see that partial studies are not only ways to reach this ultimate goal. (19)

Somehow, we can consider the studies of Arab rhetoricians like the French study, as they study linguistic structures in Arabic, where the difference is found in the significance depending on what is mentioned 
under the stylistic phenomena,such as deletion,the proper and common noun and preferring, as well as they study the methods of the limitation, separation, connection, brevity, redundancy, semanticsof formulasand the particles used in styles of the writing. This is with the need to note the differences between the French and Arabic languages in the system of performance, historical and cultural environments, in that they both lived.

In contrast to this strict stylistic approach we see that there are some other stylistic studies characterized by much flexibility, especially to some German writers, but the stylistic elements where hardly are distinct from the general literary criticism and itstypes: historical or effectual or pure literary, which is believed to be the stylistic will be played by and improve.

A clear example to these studies is (Carl Voslr), who was one of the first preachers to pay attention to the analysis of language of the text, and the result, which was ended by (Voslr), and was shared by others, that the stylistic analysis complies with the literary criticism in its "objective form". It means that it is not onlya literary criticism get rid from a personal preference based on the decision. (20)

\section{Stylistic}

Indeed, there is an importance to another direction beside the linguistic studies and leaving them as expressed by (Valerie) by saying that the stylistic looksto the literary impacts, and examinesthe means of expression and inspiration that are discovered by the writer or poet, rising the power of speech and its ability to access and influence or in the words of one of the Americancriticsit is a study beyond the logic of language in the expression (21).

This trend looks also to what is discovered by thestylistic does not have a value only to the extent that helps to understand the literary work and its absorption. By thisway, the stylistic work enters the field of literary criticism, providing the objectivity and organizedknowledge.Therefore, it gains its advantages and provisions evaluating the strength and stability. Some multiple studies fall under this type of the study, as one stylistic phenomenon of a particular literary work or group of works from one literary racemay be studied. The stylistic may study a full literary work or literary art as a whole in a particular language as (Ullman) has donein his book:"The style in French Novel" in 1957.

The study of apoet's or writer's stylemay be in his total works or most of his works, which is called Individual Style or may be study of a literary school's style such as Romanism and other literary doctrines followed in the West. The horizon of the study may be extended, to be the study of the so-called Period Style.This type of study is called by the researchers: "Formative or IndividualStylistic Study". There is a clear difference between this study and the which is called by the name: Stylistic Metadata that the latter works to identify the stylistic phenomenon and explains its expressive possibilities only, while the formative stylistic studyis based on the analysis of the taskwhich is done by the stylistic phenomenon related to the book or the author or age or art, therefore it is considered a color of Applied Criticism which is called by (Pierre Guiroud) Stylistic Criticism, as he defines the task of this criticism through the evaluation of the method used by the writer for the stylistic resources in the language.

There is anothermedial expressive form between the two well-known forms mentioned before. The first indication of the presence of this form was in an article published by Charles Bali in $1912 \mathrm{AD}$, he studiedit only as a means use in a common language. After eight years Proust mentioned in another article published in a French magazine that this means was used by Flaubert (1821-1880) as an unconscious use completely, supporting him in his saying that this form is a means of a common language. (Thibeaudet) answered him and discussed in a discourse that he was influenced in this style by his predecessors, and this discussion took a remarkable space from the fourth chapter of his book, which is issued about (Flaubert). This figure, which had used by (Lafontaine) in the seventeenth century, had become more clear in the second half of the eighteenth century, then became a model almost prevailed in the nineteenth century, whether in France or England or Germany. (22)

From the point of stylistic view, the new born figure has linked clearlyto a direction to reduce the role of the Omnicompetent Narrator as it is called in the term of critics, meaning the narrator of events that is capable to do everything in the world of the story. So this form is part of a general movement in the story emerged in the beginning of nineteenth century and continued thereafter. May it has be motivated by multiple reasons, may it has stemmed by a desire to be existed more than just being a talk about the events of the story, and may be a way to presentthe individual characters, through the images of their interior life, while retaining as much as quite a bit of control, in a greater way than can be done using only direct speech. This may be to enliven and influence by a paragraph designed to perform a particular purpose.

Perhaps the more important than which is mentioned before is that ifthe indirect free style places in its accurate position according to the standpoint of its characters, it becomes a tool of ridicule Irony, therefore this is the most important means forthe author to depend upon it to deliver his provisions and assessments without any interference to comment explicitly from his side. 


\section{The Difference between Stylistic Study and Literary Criticism}

The stylistic studies technically try to be neutral and objective. As in the General Criticismmostly the observation and analysis will beto serve a certain goal, because there are some traditionalprovisions always reexamined, and each age makes its own requirements, so the criticism also must be so, then as being one of the tasks of the stylistic study,it should offer a fixed material for the partial criticismto work on this base.

There is a large number of the stylistic means in the story, poetry and other literary arts that can be studied in similar ways, including: the arrangement of the wordsin order, repetition,musical rhythmic styles, metaphor, symbol, image and local color. Some of these means may have more attention than the others, as well as some of them may also be a greater scope and a broader range than others. However, it has been clear that there is a notable stylistic feature in a particular author can be a key to his aesthetic approach. (23)

It is noted that in the most cases of literary criticism,the importance is given to the linguistic intermittent partially, often comes unconsciously, by itself, without its own critical curricula.We often see that the critics start from the biography of a writer orpoet or literary history or history of thought, and they do not arrive at the exact thinking in the same literary work, but in the end. While the hallmark of the study of the style is that it starts from the same literary work:from the words, the way of their combination, joining each to others. There is no limit prohibited for the scholar ofthe style, but he starts his study from a specific point certainty.

According to the claim of stylistic G. Houghsays:The far fields of art to the writer, his deeper emotional experience and his highest spiritual outlook prospect, all of them does not reflect, but in his own words and can not be understoodwithout examining his linguistic art deeply. Even if we accept these claims, we must also recognize that there are some real difficulties in the process of transition from the particular characteristics in vocabularies and structures that are the starting pointfor the scholar of the style to the big considerations in the art of the writer or poet. The tool of the linguist in his work much different to the tool of the scholar ofthe literature, the first tends to note the certainties, while the second tends to the meditation and intuitive cognition. It means that there are different pictures of this perception among the scholars, because of the differences found in their mood and intellectual and emotional temperament, in addition to those real difficulties that are surrounded by this approach, many people believe thatthe ideas have a reality which has an end and that the words are not only its exhibitorclothes, and this view is justified in a large area of the writing, as being the ExpositoryProse, which is prepares by the writer according to a long tradition, because his mission to display ideas and meanings in an easy and unemotional manner, therefore probably he does not offer an special or distinctive thing in his own way of dealing with the words or displays a small amount of the material which is suitable for thestudy to the scholar of the style. Even when the writeris a creative, the scholar of literature often discovers that he has only a small amount of the training to note the correlation between the observed literary characteristics intuitively, and the linguistic means that led to it. This type of the training certainly, is that one whichcan be givenby the stylistic study as its declaration, but it must be recognized that it did not reach that point only after a period of time. (24)

This is a fact that there are two parties that are far away from each other in this kind of stylistic studies, one is represented by the pure linguistic approach, which tends to assemble the stylistic characteristics of the author, such as vocabulary, sentence structure, characteristics of the compositions and the picture... etc. these properties are classified according to a predetermined plan. There are many works that have emerged earlierin the field of this kind of stylistic study, but their literary results have not extracted. All of that, there is a range of evidencesthat can be a basefor the arrangementof these results. As well as many of the subjects recorded in a complete list may be counted from thefutile subjects, since many of the characteristics described do not have a distinctive feature and do not lead to increasethe literary understanding, and which is often presented does not have a result of thereliable note, as far as it can be used only to apply the rules of a plan automatically. The spread of this kind of studies that are empty of the aesthetic dimension or can not reach it, led many scholars of the literature to the skepticism in the stylistic action. (25)

It is natural to stop a large part of the study of personal style that revolves around the nature of the author, as the writer who has the low level may expose a little bit of the exciting means to the stylistic research, but we must always remember that his temperament and vision of humanity, and his understanding of the society of his time, whatever the characteristics that we find has not materialized only through the verbal means, so itthenmust be a viable basis for the linguistic research.If the author was difficult and complicated, the stylistic search is a clear requirement. (26)

If the pure linguistic approach represents one of the two parties that are far away from each other in the study of personal style, the literary criticism represents the other party,which deals with the stylistic issues in a non-systematic manner. This criticism tends to raise some questions without the reference to any convincing way to answer them. This criticism in its best cases may achieve a great intuitive vision or have a methodological value to change the direction of literary ideas.

Between the two previous parties that are far away from each other, the literary study which has the impact and effectiveness is found. It studies subjects that are found between the linguistic study which has the 
rigid boundaries and self-literary criticism. It may be said that there is a principle prevails mostly in the modern criticism, which means that the description requires the evaluation, but this is doubtful, becausethe exact neutral literary criticism in its assessment is not impossible and is not devoid of the benefit. The stylistic description, must has to relying on a standard model of the comparison and this model should have a close relation to the subject which is under the study. The study of style does not requirecommitted or excessive awareness of the system and its application. French critics in particular have provided a lot of bright models in the study of style, driven by a sense of responsibility toward the language, as a sense of that the French critics generally often become on the top of the English critics, as well as it is led by the elegance of the normal literary discourse its clarity, with a full dimension from being committed technically. Germans also had presented something like this, but in a way that was more scholastic and more committed technically, going along their tendency to be loyal to the regime, and writing something for the intellectual reader generally.Finally wehave to say that all studies of the real literary style generally should not be only some lists of the linguistic characteristics, but they should tend to understand the literary work. (27)

However, the objective which is characterized by the stylistic analysis of literary works has invited some stylistics to overstate the significance of the stylistic role in the literary field as "the scientific knowledge of the literature" as it is said by (Alonso Dmaso). Thus, it seems good to this team of the researchers to use the word"science" for it, saying: (Science of Style). In fact, the (stylistic) in the sense of a study of stile as mentioned,seems to be more modest, it can be a systematic study of the literary expression, but it does not reach to be a scientific study in the true sense of this word. All theallegations that turn the literary study to a science, havea large number of doubtful elements, because it is difficult that the study of personalstyle of an author which is the most prominent type of the stylistic studies- to reach the level of scientific certainty, which does not accept the denial or controversy, there will be always a place for the different opinions. The attention of scholars should be tended tothe stylistic characteristics and the relative importance of those characteristics that observed in the literary work.It is possible to point to the existence of some specific linguistic characteristics objectively,to arrange these characteristics in a system must be accepted logically and psychologically,to combine these characteristics together to be an argument that can reach at least to the degree of persuasion that did not amount to the certainty. If it is not possible or even desirable to erase the elements contemplative self in the literary criticism, there is a great logicaldeal that these elements can be on the basis of the description and analysisthat can beprovenand indicated. Here the accurate description of the stylistic study comes to be said by who said:"it is a ring between the scientific study of the language and the literary study of the style." (28). The scientific aspect of stylistic derived from the modern linguisticwith its different branches: sounds, and Semantics, and Syntax. Its literary side is based on the literary criticism. Therefore the stylisticis counted the separating zone between the two types of study that itsfeature hasnot determined yet perfectly and still has not taken a situation of its permanent establishment.

The stylistic studystretched and widened, but its scope can not cover the field of the literary study as the whole. There are many subjects that are cared by the scholars of the literature that consist onsome larger units that can be addressed by the stylistic study, such as plot, personalities and ideas coordinating, and others. (29)

\section{The Link between the Originality and Modernity in the Arab Rhetorical Studies}

No doubt that there is an urgent need to develop the rhetorical sciences as being the linguistic sciences, as thelanguages of human beings evolve and renewby the renewal of their intellectual sources. The language has to be changed by the changesin the concepts. 'Abdul 'Aziz Al-Dusuqiwanted to compare between some of the aesthetic terms, such as: "The Artistic Radiation", "the linguistic formation" and "structure of poem on the way of the painting" as being the pillars of the approach: "Artistic Vision", and between three rhetoricalsciencesin Arabic: (The meanings), (The statement) and (The science of metaphors), trying to consolidate these terms, and further clarified linking them to the Arabscientific heritage, to confirm a linkbetween the originality and modernity, because of the existence of a great similarity between these three terms and the three old Arab rhetorical sciences. So the agreement here is found in the shape and number significantly, but the three numbers that named pillars of "Artistic vision" are three terms and three pillars of Arabic Rhetoric are three Sciences.

To view the deep similarities between these three terms and three RhetoricalSciences inArabic: (The meanings),(The statement) and (The science of metaphor)we should read the nature of these three rhetorical sciences, These sciences with all its branches do not defer to be a color of (the linguistic composition), because the rhetoric in its strictest definition at the ancientscientistsis: (Agreement of the eloquent speech according to the context).

The science of (the meanings)in its essence, for example, is to know the conditions of linguisticformation of the words in the ways that make them suitable to the appropriate of a literary experience. This does not come out from the definition of the ancients "that it is ascience that thestatus of the word in 
Arabicis knownby it, asthe word matches the appropriate of the context, which means the suitable consideration of the context, as it is determined by the ancientscientists.

We chosesome words to form somesentences and structures taking into account the nature of the experience and what does it need from the predicate and subject, and deletion or separation, or combination or brevity, redundancy or equality. The basis for all this is the words and structures or what we maysay: "the linguistic composition".

We can say like this about the science "Statement" also because it is "a science to bringa indicated meaning by the identical speech,according to the requirement of the case in the context, in different ways of the compositions for the clarity of its significance.

It does not come out of what is typically known in the modern term (linguistic composition), because it means some different formations of the words of the language and their structures that are used in different ways to denote the meanings.

This is also can be said about(the science of the metaphors), that belong inherently to some linguistic formations directly,that come from the alliteration or counterpoint or partition orother branches of this science.

Here 'Abdul 'Aziz Al-Dusuqīhas decidedthat we can dispense with the term "linguistic composition" for many of the ramifications of these rhetorical sciencesthat are complicated and have been branching out and growing, until they turned into a very difficult divisionto be understood. (30)

Then he said: it is a requirementto define the nature of the curriculum: (Artistic Vision) and its relationship with its three pillars: (Linguistic Composition), (Artistic Radiation) and (structure of poem on the wayof the painting).

If we are satisfied by this clarification, the relationship between these three terms that are considered as the pillars of the approach: (Artistic Vision) turns intoan intimate membership.

The "Linguistic Composition"and "structure of poem on the way of the painting"is the body of this approach and the "artistic radiation"is its sprit, it means that it is an integrated approach deals with the literary and artistic experience, maintaining this experience with its aesthetic characteristic and nature more conservatively and in a perfect scientific manner, at the same time it does not go far away from the nature of the beauty. By this way,it differs to some rhetoricalresearches in Arabic that turn into some strictlogical measurements or coldmental looks or dry ramifications, because of the nature of these sciencesthat could not be implemented directly to the technical glare warm which is found inside the literary experience. For this there was an urgent need to a modern rhetorichas fully difference from the old Arab rhetoric though has taken the guidelines from its methodologies, looks of its scientists, their perceptions and methods of their analysis of the text.

Then he called to this approach: "Artistic Vision"with its three pillars, as a literary approach deals with the literary experience and tries through its technical tools to discover the meaning of beauty and splendor of the art in this experience, and goes to the essence of linguistic compositions, and styles of beauty in the artistic work, without resorting to the ramifications or pro forma divisions that do not serve the nature of an artistic experience.

He does not deny that some of the old rhetorical books may have had a significant role in enriching the literary experience, but the theoretical basis of this science is that one made it standing at the edge of the formalism and did not let it play the role of aestheticscience or the literary criticism. While it was better tothis rhetoric topushthese two sciences stronglyto be grown and advancedin Arabic without being busy with this theoretical basis, that is "a matching eloquent speech to the case in its context". The case is to take into account the appropriate consideration for the placegrammatically.

In his view the rhetorical experience -in its most part- has beenlinked to the person addressed by the speech, means the reader or the listener and does not care about the text itself, and does not bother the writer of the text, but puts in its mind the recipient of the text and the conditions of his mental ratification or denial, so that, the speech comes out matchingto the condition of that person. This matching is called "rhetoric" in Arabic.

He believes that strong mental reasoning in Arab rhetoric impressed those who were living in an atmosphere, wherethe science oflogic,philosophy, and jurisprudential provisions and scholastic debateswere flourished and all intellectual knowledge was impressedby this logical and philosophical influence, but at the same time this influence killed the literary experience. (31)

We say: It is true that Arabic rhetoric has flourished in a certain era,when the science of logic, philosophy, schools of Islamic jurisprudence and Arab rhetoric flourished, and these science were useful in their time, but we do not accept that this rhetorical science killed theliterary experience, and that it made itself standing at the edge of the formalismand did not play the role of aestheticscience or the literary criticism. We do not acceptalso that it ignored to discover the beauty of meaning and splendor of the art in the literary experience.

Those who say that rhetorical sciences remained mostlyassociated with the reader or recipient of the speech, that is, they do not care in the text itself, nor bother the writer of the text, we say to them that it seems that they did not study the issue of the word and meaning or the form and content, or the thought and its 
Technical mold that was matured at 'Abdul QāhirAl-Jurjānī. So we briefly mention here for them what was said by 'Abdul Qāhir in this case in the following. (32)

\section{Research Finding: Rhetorical System of Style in Arabic}

First: we examine the advantages of the approach: (System of Speech and Grammar)by 'Abdul QāhirAl-Jurjānī, which is characterized in resolving this issue.

A. 'Abdul Qāhirlooks that the word is a symbol for its meaning.It is supported by the old and modern critics, and the school of symbolization in the language. So the word is a symbol forthe thought or the experience or emotion or meaning, and its value is as it stands, not in the rhetoric alone.

B. Stylistic Relations -in the opinion of 'Abdul Qāhir- amongthe words are seen in the rhetorical science, that were expressed by the system (of the speech), and that are expressedat the critics by the form or image. The imagein the literary text is composed by a set of relations amongthe words, where the rhetoric or aesthetic style is shown.

C. 'Abdul Qāhir does not ignore the importance of the secondary meanings as it is necessarily or the phrases that come after the compositions or effect of the symbolic voices of the pronunciation or psychological overtones, because all these give the style its rhetorical meanings, and aesthetic value.

Second: Theory of "Abdul Qāhir"the system of style" is made of all these values that he has a connected themto the word and meaning, and the stylistic semantics and secondary implications, as he made "the system" alone the appearance of rhetoric and aesthetic value in the literary text and displayedit for the literary application, in this way, and clarified it in his book: (Signs of Miracles) in a bright image and in a statement explained clearly, but he did not move like the other Arab critics to the idea ofunitingthe literary work, as the whole, but he intended to a single literary image, as the literary work is made of these images as the whole. As we can see SuhairQalmāwī makes it limited in the tool and images. (33)

The tool is the language and the images are artistic forms issued bythe text. The point of difference between SuhairQalmāwiand the other critics is only the formality, because as long as we see that the images specified by SuhairQalmāwiare: the epic story, article, play and poem, as it is recommended that these all species can be collected under the so-called the literary genres. It is notable that these images were called bythe ancient rhetoriciansthe analogy, metaphor and which is mentioned under the metaphor. (34)

Saying thatthe rhetorical experience does not care about the text itself and does not bother author of the text, but puts in its mind the recipient of the text and his psychological conditions only, (35) is not correct. Because the issue is the composition of speech, the speech can not be existed without the speaker. The composition of speech is an art, each art needs in its existence to the artist, and this is understood. So if the discussion is in the industry, it follows of course the manufacturer in the terms of quality: good and bad. So we say that the literature of a writer is the writer himself, because we see in his literature his own experiences. Therefore, we shall be always ahead of the text and its author. If we want to talk about his literary work, we should talk about it through all his literary works. We consider this saying false "that the Arab rhetoric does not care only the recipient of the text". The objective speech is that we see the speaker taking care of the level of the readers or listenersin his speech, as the environment and culture, because the goal of literary speech is to transfer the literary experience to other souls on their levels. Arab rhetoric did not ignore the text and writer of the text nor level of the recipient of the text. So such a saying is just a saying only, has no base to be said that it is correct...

If we want to develop a modern rhetoricin this contemporary age, replacing the old Arab rhetoric, we must provide it with an alternative approach to the approach of "Abdul Qāhir in "the system of speech", in line with the nature of Arabic language. As for we see the subject of simile and metaphorand their sorts, and the other pictures of metaphorin Arabicmore systematic than any language. This is a mater can not be ignored by anyone.

We can conclude from everything that goes on around the text some types of foundations, make the process of evaluationeasierfor thecritic,depending on them in his analysis and interpretation, but the problem of the text is larger than providing it some solutions, which strikes at the core of the language and in the same time hasbelongs to therhetorical extensions.It is also involved with the music in the rhythm, and also raises the issue of the content in the presentation of phrases.

Creating a modern rhetoric is not easy, and the biggest evidence of the difficulty is the different views about the nature of the literary word. The truth is that the wordsare a set of codes have their voice. (36) When they grow and develop, their meanings become strict objectivity. It is very hard to the writer to play a role indevelopinghis own dictionary, as far as if he succeedsin the liquidation from the traditional heritage he must succeed in giving his imaginary dimension to the heritage. It meansthat he has to faces two battle fields:The firstis to get rid of the old stereotypes. The other is to get rid of the termsof the intellectual era and follow some subsequent methods closer to the public's orthe reader'sexpressions generally. 
The writer who chooses his dictionary can put its material according to the agreement requiredby each.., without a curiosity, tightness and narrowness. Therefore the issue of suitability of the text to the experience becomes asubject of the fertile debates, but this matching requires something else, that is the musical word or internal rhythm of the words. In fact, the semantics has no existence without theknowledge of the musical words. If there is a correlation between the word and its sound there is no doubt that this correlation depends on the meaning, thereafter the relationship between the sound and meaning remains a sound relationship. So if there is a case of prefixing or delaying, and deleting ormentioning, and likethat, sothat it is needed by the musical phrase as much as by the meaning. Thus we see the single word and the complete sentence and the consistency between the words frequented inside of rhythm... We see all that activates the critic inside the text, as he can be assisted by the valuableviews left by 'Abdul Qāhir Al-Jurjānīin "the system of speech", and like him other rhetoricians who had also some opinions that are not less intelligent than opinionsof Richard and other analytics in Europe and America. (37)

The theme of "the development of the poem on the way of painting", it is not just a term as 'Abdul 'Aziz Al-Dusuqi sees, but it is a stand-alone doctrine in the field of lyric poetry, sometimes called: Doctrine "La Parnassecontemporain", and sometimes Technical doctrine, which has taken the art to be the end in itself, not a means for self-expression, as beinga beautiful art, its act is to carve pictures and the beautiful thought from the language somehow the statues of marble are carved andthe paintings are colored.Obviously this doctrine can not be achieved However, in the Description field, because this doctrine want to make the poetrya technical objective art has an end in itself, its goal is to carve the beauty or create it orbring it out of the appearances of the beauty in the natureor wear it on those appearances. (38)

Although, this doctrine "Parnasse" was keen to the objectivity and taking the anthropomorphism or sculpture a basic goal of the poetry, so that -for example-the Description comes to present the image, covering allthe external qualities and characteristics, as artist carves the statue, but this attempt was not possible nor good to be realized in absolute terms, otherwise the poetic Description became a Sirius automatic Calvin like the art of photography, because the poet often reflects his gaze to the same inside. To see in its mirror outside world reflected therein, and when he describes the world he does not describe as it is seen outside, but he describes as he sees reflected in the mirror of his soul.This psychological mirror must color the outside world with its especial color as much as it can, consciously or unconsciously. All of this belongsaccordingly due to the differences in the natures of the poets and the ability of sensitivity in the mirror of all the same. (39)

'Abdul 'Aziz Al-Dusuqi has to pay his attention to that "the poem on the way of the artistic painting" is not only a term, but it is a doctrine has a philosophy appeared against the romantic trend in Europe.

Briefly we can say about this philosophy that Kant was the greatest one of those who differentiates between the beauty itselfand benefit of the beauty. So the artistic work has some fundamental characteristics that provide it a recipe of the beauty and sheer beauty is not shown, but only in its form. As if thereis a world where anythingis not found except the beauty was an end in itself. This is called by (Kant): " "finality without very"in the beautiful thing. The followers of doctrine "Parnasse" had influenced by this philosophy to make the poetry independent from all of the social or moral goals.

The first one who chanted echo of this philosophy in France is Benjamin Constant (1767-1830 AD) in his special diary printed in 1895 , then appeared the phrase "the art for the art" in lectures of Victor Cousin, that were delivered at the Sorbonne in 1818, and printed in 1836, entitled: lectures in philosophy: (Cours de Philosophie), which included: "the Sharia (Revealed Law) is for the religiousmatters, the creation isfor the creation and the art is for the art". The artcan not be a source of the benefits, not for the good thing and not for the things sacred, because the art does not lead only to the very same" (40).

So it is clear that the idea of (building poem on the painting style) is taken from a literary doctrine: "The art is for the art" or "Parnasse". Here we note the difference between the Arab rhetoric and the issue of (the art is for the art) so that rhetorical science does not bother the external appearance of the literature, but also interested in the meanings. The system of meanings is being a motivation for the system of words and structures according to the grammatical rules.

Moreover, 'Abdul 'Aziz Al-Dusuqi understands that the meaning of "the agreement of words to the requirement of the case in the context" is that the speech has to be according to the case of recipient of the text, but the matter is not so, but the meaning of "the agreement of words to the requirement of the case in the context" is the grammatical context, means that the system and arrangement of the words has to be according to the requirements of Arabic grammar, to be the system of speech according to the grammatical rules, as the pears are organizedin the necklaces. This is the meaning of Jurjāni's saying: "The single word has no importance only inside the sentence". It seems that he accused by the misunderstanding Arabic Rhetoric that it puts the recipient of the text (the addressee) and his psychological conditions only in the account. This is a kind of falsification and misdeed to the status of three rhetorical sciences in Arabic: (The meanings), (the statement) and (the metaphor).So "the linguistic formation"which we may call it the outward appearance of the literature, can not be found without these rhetorical sciences, particularly approach of 'Abdul Qāhir in "the system of speech and 
grammar". We mean that the language -all the languages-has its possibilities and the literary work as being a linguistic structure exploits as much as it can to use these possibilities, but this construction does not take a natural form, because it is not a formal planning engineered. The literature uses a kind of some particular expressive tools provide the possibilities of music on the one hand, as well as it follows in its composition a special formational system. The literature -after all this or before- is not a musician and not a sculpture.The poet or writer that seems to him that he can create in his literary work a musicalstructure is a not a real poet or writer, because "the music" is a massive free-standing Art and all of its possibilities are found behind the possibility of the speaker language permanently. (41)

As well as the writers who think by their misunderstanding that they can perform the task of a formativeart in the language and that they may simulate the artists looking at the material pictures that fall under the eyes or as counting their work as one of the formative arts. Then that these possibilities in the language are a means, not an end. Is it not better to say that the literary work which has a linguistic structureuses advantage of all the possibilities of the functions of a musical,pictorial and symbolic and expressive language to transmit to the receiver a new passive experience of life?

It is notable that there is a disorder and confusionbetween these stylistic terms and literary criticism, especially modern literary doctrines, such as romantic and doctrines followed such as "Parnasse" and symbolic school, these literary doctrines were borrowed and were useful in the development of modern literary criticism, after the development of Arabic literature through its connection to literature European in the modern era, but the rhetorical criticism in or the rhetorical science at the Arabs in its ancient time were and are still useful in the process of criticizingthe texts in Arabic, but the stylistic terms that we study today's in the modern era are not a new thing to the old rhetoricians. It can be better to say that these attempts are like some small rivers dripping in a broad sea of the rhetorical sciences in Arabic. The approach of 'Abdul Qāhir(the system of speech or style) should be studied by the critics in the West again hoping that this approach will be useful to them, which is not contrary to the mind and logic, as the mindis a jewel fixed to benefit the human in every place and every age.

[1]. Buffon: Discourse sur le style, Librairie, hatier, Paris, 1920, p. 17

[2]. Middleton Murry: The Problem of Style, Oxford Univ. Press, London, 1930, p. 14

[3]. Ibid, pp. 71-72

[4]. 'Izz Al-Din (Dr.): The literature and its arts, (Forth Edition), House of the Arab thought, Cairo, 1968, pp. 36-37

[5]. Peter Westland: Literary Appreciation, English Universities Press, London, 1950, pp. 71-75

[6]. 'Izz Al-Din (Dr.): The literature and its arts,pp. 40-41

[7]. Ibid, p. 76

[8]. J. Middleton Murry: The problem of style (London: rep, 1967), pp. 4-7

[9]. Shafic Al-Sayyid (Dr.): Stylistic Direction in the Literary Criticism, House of the Arab thought, Cairo, 1986, p. 132

[10]. C. F. Hockett: A course in Modern Linguistics (New York, 1958), p. 558

[11]. Saa'dMașlūh (Dr.): The Style (A Linguistic Study), House of the scientific research, Kuwait, (First Edition), 1980, p. 25-73

[12]. Ibid, p. 136

[13]. G. Hough, op.cit, p.8

[14]. S. Ulmann: Meaning and Style (Oxford, 1973) p. 40

[15]. 'Abdul Qāhir(Al-Jurjān̄i): Signs of Miracles, investigated by: MaḥmūdShākir, Cairo, KhānJi Library, 1984, p. 489

[16]. Saa'dMaslūh(Dr.): The Style (A Linguistic Study), House of the scientific research, Kuwait, (First Edition), 1980, p. 25-73

[17]. 'Abdul Qāhir (Al-Jurjānī): Signs of Miracles, investigated by: MaḥmūdShākir, Cairo, KhānJi Library, 1984, p.486

[18]. S. Ulmann, op. cit, p. 4

[19]. ShukriMuhammad'Ayāḍ (Dr.): A way to the science of style, (Firs edition), Saudi Arabia, 1982, p. 62

[20]. G. Hough. op. cit. pp. 31-33

[21]. S. Ulmann, op. cit, p. 41

[22]. Shafi'Al-Sayyid (Dr.): Stylistic Direction in the Literary Criticism, House of the Arab thought, Cairo, 1986, p. 150

[23]. Ibid, p. 36

[24]. G. Hough, op, cit, p. 40

[25]. Shafi'Al-Sayyid (Dr.): Stylistic Direction in the Literary Criticism, House of the Arab thought, Cairo, 1986, p. 154

[26]. Ibid, 158

[27]. G. Hough, op. cit, p. 43

[28]. R. C. Sayce, op. cit. p. 3

[29]. Shafi'Al-Sayyid (Dr.): Stylistic Direction in the Literary Criticism, House of the Arab thought, Cairo, 1986, p. 162

[30]. 'Abdul 'Aziz Al-Dusuqī (Dr.): The artistic Vision and Arab Rhetoric, (Article), Magazine of "The Culture", Feb. 1979, p. 60-61

[31]. Ibid, p. 62

[32]. Muhammad'Abdul Mun'imKhifājī (Dr.) Preface of the investigated book "Signs of Miracles", Cairo Library Press, p. 21

[33]. SuhairQalmāwī (Dr.): A Lecture in Literary Criticism, International Institute of Arabic Studies, 1955, p. 54

[34]. Ahmad KamālZaki (Dr.): Studies in Literary Criticism, House of Andalusia, Beirut, 1980, p. 17

[35]. Magazine of "The Culture", Feb. 1979, p. 60-61

[36]. Stephen Ulmann: Words and their use, Translated by: KamālMuhammadBishr under the title: "Role the word in the language", see also Richard Trench: "Study of Words", London, 1910

[37]. Aḥmad KamālZaki (Dr.): Studies in Literary Criticism, House of Andalusia, Beirut, 1980, p. 18-20

[38]. MuhammadMandūr (Dr.): The literature and its schools, p. 110

[39]. Ibid, 116-117

[40]. MuhammadGhunymīHilāl (Dr.): Comparative Literature, Anglo-Egyptian Library, Cairo, 1962, p. 386-387

[41]. J. Middleton Murry: The Problem of Style, Oxford Univ. Press, London, 1930, p. 87 